\title{
Islam, Fatwa dan Negara: Meretas Pluralisme Hukum Perceraian di Aceh
}

\author{
Muhazir \\ Fakultas Syariah IAIN Langsa \\ Jl. Meurandeh, Meurandeh, Langsa Lama, Kota Langsa, Aceh \\ Email:muhazir@iainlangsa.ac.id
}

\begin{tabular}{llll} 
Submit & $: 20$ Juli 2021 & Diterima & $: 25$ Agustus 2021 \\
Revisi & $: 11$ November 2021 & Terbit & $: 1$ Desember 2021 \\
\hline
\end{tabular}

\begin{abstract}
The pluralism of divorce in Aceh has had an impact on the current practice of divorce. Fatwa, Jurisprudence, and the State also color the pluralism of divorce law, each of which has a normative and sociological power base. The Aceh MPU's fatwa tends to legitimize divorce regulated in figh books while the State has a different view of divorce law. This paper is a doctrinal study with a legal pluralism approach. This article argues that in substance there is a significant difference between the divorce provisions in fatwa, figh, and state law. Fatwa and figh share the same view that divorce without witnesses and taking place outside the court is still valid, as well as triple talaq, whether pronounced cumulatively or separately, is still subject to triple talaq, this provision is different from divorce law which is regulated by the state and practiced in religious courts.
\end{abstract}

Keywords: Legal Pluralism, Divorce, Ulama Consultative Council, Fatwa

Abstrak: Pluralisme hukum perceraian di Aceh memberikan dampak terhadap praktik perceraian yang selama ini berlangsung. Fatwa, Fikih dan Negara turut mewarnai pluralisme hukum perceraian yang masing-masing memiliki basis kekuatan baik secara normativ maupun sosiologis. Fatwa MPU Aceh cenderung melegitimasi perceraian yang diatur dalam kitab fikih sedangkan Negara memiliki pandangan berbeda terhadap hukum perceraian. Tulisan ini merupakan kajian doktrinal dengan pendekatan pluralisme hukum. Artikel ini beragumentasi bahwa secara subtansi ada perbedaan yang signifikan antara ketentuan perceraian dalam fatwa, fikih dengan hukum Negara. Fatwa dan fikih memiliki pandangan yang sama bahwa perceraian tanpa adanya saksi dan terjadi di luar pengadilan tetap sah, begitu juga dengan talak tiga baik diucapkan secara kumulatif maupun terpisah tetap dijatuhi talak tiga, ketentuan ini berbeda dengan hukum perceraian yang diatur oleh negara dan yang dipraktikkan pada pengadilan Agama.

Kata Kunci: Pluralisme Hukum, Perceraian, Majelis Permusyawaratan Ulama, Fatwa

\section{Pendahuluan}

Pluralisme hukum perceraian di Aceh bukanlah hal baru, dengan beckground masyarakat Aceh yang kental dengan adat dan Islam, sejatinya telah menggambarkan bagaimana relasi adat dan Islam menyatu dalam setiap aktifitas. John R. Bowen melalui penelitianya di Aceh telah menggambarkan bagaimana agama, hukum dan adat hidup meskipun terkadang tidak terlepas dari perdebatan- 
perdebatan. ${ }^{1}$ Pluralisme hukum di Aceh semakin berkembang pasca Memorandum of Understanding (MoU) antara Gerakan Aceh Merdeka dan Pemerintah Indonesia. Efek dari MOU tersebut memberikan keleluasaan kepada pemerintah Aceh untuk membangun hukum berdasarkan syariat Islam. ${ }^{2}$ Apalagi dengan diberlakukannya otonomi khusus di Aceh semakin memperkuat kewenangan pemerintah Aceh dalam menghudupkan hukum yang bernuansa syariat dan adat. ${ }^{3}$ Lembaga adat dihidupkan kembali bahkan diatur dalam undang-undang tersendiri. Tidak hanya itu saja, Majelis Ulama Idonesia berubah wujud menjadi Majelis Permusyawaratan Ulama (MPU). Begitu juga dengan peradilan agama berubah menjadi Mahkamah Syar'iyah. ${ }^{4}$ adanya Dinas Syariat Islam dan wilayatul hisbah (polisi syariah) semakin melengkapi eksistensi penerapan syariat Islam di Aceh. Transformasi ini terjadi ketika pemerintah pusat memberikan keleluasaan kepada pemerintah Aceh untuk membentuk aturan hukum sendiri dengan sistem pemerintahan disentralisasi. Bentuk disetralisasi dilakukan untuk memperbaiki komitmen dan tidak melepaskan fungsi sentral pemerintahan. ${ }^{5}$

Pemberlakuan hukum adat dan Islam di Aceh sudah lama terbentuk sebelum Indonesia Merdeka, dalam sejarah perjuangan kemerdekaan Indonesia, Aceh memiliki peran penting dalam mencapai kemerdekaan. Sehingga tuntutan penting yang di Inginkan oleh Ulama Aceh pada sat itu adalah menerapkan Syariat Islam pasca-kemerdekaan. ${ }^{6}$ Ulama bagi masyarakat Aceh memiliki posisi sentral dalam aktifitas keagamaan. Tidak hanya itu saja, bahkan dalam konteks sosial, Ulama dengan pengaruhnya turut membantu pemberantasan narkoba di Aceh. ${ }^{7}$ Kedudukan MPU semakin menguat pasca diberlakukannya syariat Islam di Aceh. ${ }^{8}$ Sehingga sudah sewajarnya fatwa memiliki pengaruh bagi masyarakat Aceh.

Secara histori, adat dan Islam sejak lama telah hidup pada masa kesultanan Aceh. Bahkan syariat dan adat hidup berdampingan dan tidak dibedakan satu sama lainnya. ${ }^{9}$ Sebagaimana hadih madja (pepatah) "hukom ngon adat, lagee zat ngon sifeut (syariat dan adat seperti zat dan sifat). ${ }^{10}$ syariat dan adat menyatu dalam segala aktifitas sosial terutama yang berhubungan langsung dengan praktik hukum. Meskipun begitu, pasca-keemrdekaan peraturan pemerintah tetap menjadi satu rujukan ketika syariat dan adat tidak mengatur. Pergesekan antara syariat, adat dan negara terjadi pasca pemerintah mengatur ranah-ranah privat yang secara mendasar telah diatur dalam syariat dan adat Aceh. Friksi tersebut muncul ketika masyarakat, ulama berbeda pandangan dengan pemerintah, seperti hukum percerian.

1 John R Bowen, Islam, Law, and Equality in Indonesia an Anthropology of Public Reasoning (Cambridge, UK; New York, NY: Cambridge University Press, 2003), 2-3.

2 Darmansjah Djumala, Soft Power untuk Aceh (Jakarta: Gramedia Pustaka Utama, 2013).74-76

3 M. N. Ichwan, "Official Ulema and the Politics of Re-Islamization: The Majelis Permusyawaratan Ulama, Sharilhringatization and Contested Authority in Post-New Order Aceh," Journal of Islamic Studies 22, no. 2 (May 1, 2011): 183-214, https://doi. org/10.1093/jis/etr026.

4 R. Michael Feener, Shari'a and Social Engineering: The Implementation of Islamic Law in Contemporary Aceh, Indonesia, First edition, Oxford Islamic Legal Studies (Oxford, United Kingdom: Oxford University Press, 2013)., xii

5 Regime Change, Democracy and Islam: The Case of Indonesia (Belanda: Universiteit Leiden, 2013)., 133

6 Arskal Salim, "Dynamic Legal Pluralism in Indonesia: Contested Legal Orders in Contemporary Aceh," The Journal of Legal Pluralism and Unofficial Law 42, no. 61 (January 2010): 1-29, https://doi.org/10.1080/07329113.2010.10756640.

7 Nirzalin Nirzalin and Yogi Febriandi, "Teungku Dayah Agency and Religious Social Capital on Drug Eradication in Aceh, Indonesia," Jurnal Ilmu Sosial Dan Ilmu Politik 23, no. 3 (May 21, 2020): 210, https://doi.org/10.22146/jsp.51061.

8 Ichwan, "Official Ulema and the Politics of Re-Islamization."184

9 Salim, "Dynamic Legal Pluralism in Indonesia." 4

10 Jamhir Jamhir, "Revitalisasi Hukum Adat Di Aceh," Jurnal Justisia :Jurnal Ilmu Hukum, Perundang-Undangan Dan Pranata Sosial 1, No. 1 (2020):68-90, https://doi.org/10.22373/justisia.v1i1.2562. 
Perceraian merupakan ranah privat yang berkaitan langsung dengan hukum agama. Dalam hal ini masyarakat lebih cenderung kepada pendapat Ulama-Ulama Aceh. Ulama Aceh melalui MPU telah mengeluarkan fatwa tentang talak. Dalam fatwa MPU Aceh substansi hukum perceaian sama halnya dengan ketentuan perceraian yang ada dalam kajian fikih mazhab Syafi'i, karena diketahui bahwa ulama dan masyarakat Aceh sangat kental dengan kitab fikih bermazhab Syafi'i. ${ }^{11}$ Dalam permasalahan perceraian permerintah Indonesia ingin menyatukan konsep perceraian. Namun, mengingat pluralitas budaya dan agama menimbulkan friksi yang pada akhirnya terjadi pemilihan hukum apakah menggunakan hukum Islam atau hukum negara. Ada perbedaan mendasar tentang konsep perceraian antara pemerintah dan masyarakat Aceh. Perbedaan ini terletak pada cerai talak. Peraturan perkawinan di Indonesia menegaskan bahwa cerai talak yang diputuskan oleh pengadilan agama tergolong talak ba'in sugra, sedangkan pada masyarakat Aceh memiliki pemahaman bahwa cerai talak yang dijatuhkan oleh suami diklasifikasikan kedalam beberapa hal yaitu talak raj'iy, ba'in sugra dan ba'in kubra.

Pluralisme hukum perceraian semakin eksis tatkala MPU turut melegitimasi kebenaran cerai talak versi fikih mazhab Syafi'i. ditambah lagi dalam fatwa MPU Nomor 2 Tahun 2015 tentang talak didasari oleh kegelisahan hukum masyarakat tentang status hukum cerai talak yang diucapka oleh suami sebanyak tiga kali. Meskipun penelitian yang dilakukan oleh Muhammad Salamudin, A.Hamid Sarong dan Muzakkir Abubakar menjelaskan bahwa fatwa tersebut memiliki dampak negatif terhadap perceraian ketika dilihat dari aspek perlindungan hukum. Tampaknya, dampak tersebut tidak menjadi persoalan bagi sebagian masyarakat Aceh .

Pluralisme hukum sejatinya tidak hanya terjadi di Aceh saja, Ikhwanuddin Harahap juga pernah meneliti tentang pluralisme hukum perkawinan pada masyarakat Tapanuli Selatan. ${ }^{12}$ begitu juga dengan Hanisah Binte Abdullah Sani tentang pluralisme hukum, ${ }^{13}$ Arskal Salim, ${ }^{14}$ Novita Dewi Masyithoh, ${ }^{15}$ dan Mies Grijns dan Hoko Horii ${ }^{16}$ yang mendudukan dua konsep hukum berbeda antara undang-undang perkawinan dan norma hukum agama dalam batas usia nikah. Beberapa penelitian tersebut menkaji bagaimana pluralime hidup. bahkan tidak terkadang dalam keonteks tertentu pluralisme tidak selalu berjalan dengan baik dan pluralisme juga tidak menafikan friksi-friksi hukum ketika diaplikasikan pada masyarakat. Artikel ini betujuan untuk menganalisis pluralisme hukum perceraian di Aceh dan berusaha menganalisis friksi hukum perceraian yang terjadi di Aceh baik dari sudu pandang normatif, sosiologi, antropologis dan filosofis.

\footnotetext{
${ }^{11}$ Zulkarnain Zulkarnain, "Dinamika mazhab Shafi'i dengan cara Aceh: Studi tentang praktik mazhab di kalangan tokoh agama," Ijtihad:Jurnal Wacana Hukum Islam dan Kemanusiaan 15, no. 2 (January 22, 2016): 159, https://doi.org/10.18326/ijtihad.v15i2.159176.

12 Ikhwanuddin Harahap, "Pluralisme Hukum Perkawinan Di Tapanuli Selatan," MIQOT: Jurnal Ilmu-ilmu Keislaman 43, No. 1 (2019): 64, https://doi.org/10.30821/miqot.v43i1.656.

13 Hanisah Binte Abdullah Sani, "State Law and Legal Pluralism: Towards an Appraisal," The Journal of Legal Pluralism and Unofficial Law 52, no. 1 (January 2, 2020): 82-109, https://doi.org/10.1080/07329113.2020.1727726.

14 Salim, "Dynamic Legal Pluralism in Indonesia." 4

15 Novita Dewi Masyithoh, "Dialektika Pluralisme Hukum: Upaya Penyelesaian Masalah Ancaman Keberagaman dan Keberagamaan di Indonesia," Walisongo: Jurnal Penelitian Sosial Keagamaan 24, no. 2 (December 15, 2016): 359-78, https://doi. org/10.21580/ws.24.2.1289.

${ }^{16}$ Mies Grijns and Hoko Horii, "Child Marriage in a Village in West Java (Indonesia): Compromises between Legal Obligations and Religious Concerns," Asian Journal of Law and Society 5, no. 2 (November 2018): 453-66, https://doi.org/10.1017/als.2018.9.
} 
Jenis penelitian ini doktrinal. ${ }^{17}$ Penelitian doktrinal dilakukan untuk, menganalisis, mendeskripsikan, mengkritik aturan hukum yang telah tetapkan dalam dokumen-dokumen resmi. ${ }^{18}$ artikel ini akan menganalisis akar pluralisme hukum perceraian yang terjadi di Aceh antara Adat, fatwa dan peraturan-peraturan pemerintah tentang perceraian. Pendekatan yang digunakan yaitu pluralisme hukum (legal pluralism). ${ }^{19}$ Pendekatan tersebut digunakan untuk menelaah lebih jauh tentang pluralisme hukum perceraian yang terjadi pada masyarakat Aceh. Untuk mendapatkan hasil penelitian komprehensip, peneltian ini juga menggunakan penelitian-penelitian empiris yang pernah dilakukan oleh peneliti sebelumnya.

\section{Dinamika Pluralisme Hukum}

Pluralisme hukum (legal pluralism) diartikan sebagai interaksi berbagai sistem hukum dalam bidang sosial, pluralisme hukum juga dipandang sebagai suatu keadaan empiris masyarakat ${ }^{20}$ atau realitas hukum. Sema halnya dengan pernyataan For Shah bahwa:

Legal pluralism is indicative of a factual state of affairs whereby different norm systems are coming into interplay with each other with complex result. ${ }^{21}$

Eugen Ehrlich (1862-1922) yang merupakan ahli hukum Austria terkenal dengan teori "living law" telah memberikan pengaruh terhadap konsep hukum, Ehrlich telah menegaskan tentang perbedaan penting antara hukum yang ada di buku dan hukum yang hidup dimasyarakat. ${ }^{22}$ Lebih jauh Ehrlich juga telah mendiskusikan legal pluralism dengan detail, Ehrlich menyatakan bahwa hukum berangkat dari fakta sosial yang bergantung kepada sosial dari pada negara, menurutnya hukum hanya dapat dipahami dari perspektif sosiologi. Ehrlich menambahkan bahwa hukum telah hidup dan berkembang sebelum hukum negara ada, beberapa aturan seperti pernikahan, bisnis dan institusi sosial lainnya lebih dulu hidup ketimbang hukum negara. Oleh karena itu, hukum yang hidup dimasyarakat harus diberi posisi sama dengan hukum negara. ${ }^{23}$ Pluralisme hukum juga diartikan sebagai situasi dimana hukum yang berlaku bagi semua masyarakat tidak hanya satu hukum saja bahkan lebih. Kebanyakan pluralisme hukum terjadi karena hukum yang berbeda digunakan partikuler kelompok-kelompok yang disebut "tribal societies". ${ }^{24}$ Senada dengan Lawrence M. Friedman yang menyatakan bahwa pluralisme hukum memiliki arti keragaman sistem atau budaya hukum yang berbeda dalam sebuah politik tunggal. lebih jauh Friedman menggambarkan bahwa pluralisme hukum berhubungan dengan budaya, politik dan sosio-ekonomi. ${ }^{25}$

\footnotetext{
17 Ahmad Zuhdi Muhdlor, "Perkembangan Metodologi Penelitian Hukum,” Jurnal Hukum dan Peradilan 1, No. 2 (2012): 189, https://doi.org/10.25216/JHP.1.2.2012.189-206.

18 Amrit Kharel, "Doctrinal Legal Research," South African Journal of Higher Education 32, no. 1 (2018): 86, https://doi.org/10.2139/ ssrn.3130525.

19 Dedy Sumardi, "Islam, Pluralisme Hukum dan Refleksi Masyarakat Homogen," Asy-Syir'ah: Jurnal Ilmu Syari'ah dan Hukum 50, no. 2 (2016): 24.

20 John Griffiths, "What Is Legal Pluralism?," The Journal of Legal Pluralism and Unofficial Law 18, no. 24 (January 1986): 1-55, https://doi.org/10.1080/07329113.1986.10756387.

${ }^{21}$ Latif Tas, Legal Pluralism in Action: Dispute Resolution and the Kurdish Peace Committee (Farnham, Surrey, UK England: Ashgate, 2014). 15

22 Suri Ratnapala, Jurisprudence: An Introduction. (Leiden: Cambridge University Press, 2009).207

23 Werner Menski, Comparative Law in a Global Context the Legal Systems of Asia and Africa (London: Cambridge University Press, 2006). 92-93

${ }^{24}$ Lauren Benton and Richard J. Ross, Legal Pluralism and Empires, 1500-1850 (U.S.A.: NYU Press, 2013). 262

${ }^{25}$ Lawrence M. Friedman, The Legal System: A Social Science Perspective (New York: Russell Sage Foundation, 1975). 257
} 
Merry membagi kajian legal pluralism kepada dua kategori; Pertama classical legal pluralism yang dihasilkan dari penelitian pada masa masyarakat kolonial dan pasca-kolonial, penelitian ini mencoba menganalisis persinggungan hukum adat dan eropa. Kedua yang dikatakan new legal pliralism (akhir 1970-an) lebih kepada penerapan konsep pluralisme hukum pada masyarakat non-kolonialisme seperti negara eropa dan amerika serikat. ${ }^{26}$ Pengaruh globalisasi mengarahkan negara-negara di Eropa untuk mengkaji dan menerapkan pluralisme hukum.

Pada abad 20, kajian Legal pluralism menjadi daya tarik bagi para akademis dan praktisi hukum eropa, mereka mengkaji bagaimana penggunaan pluralisme hukum yang dilakukan di negaranegara Asia dan Afrika dimana adat, agama dan hukum negara dipraktikkan tanpa menggunakan hukum eropa. ${ }^{27}$ Secara historis, pasca kemedekaan yang diperoleh dari negara-negara eropa. Seperti Negara Replubik Sierra Leone yang terletak di Afrika, ${ }^{28}$ Botswana bagian afrika selatan, ${ }^{29}$ Singapore,${ }^{30}$ Indonesia yang masih menggunakan peninggalan hukum kolonial meskipun dielaborasi dengan kearifan lokal, dan beberapa negara eropa yang saat ini menerapkan pluralisme hukum seperti Argentina, ${ }^{31}$ Brazil, ${ }^{32}$ German, UK, ${ }^{33}$ Salamon Island. ${ }^{34}$

Masing-masing negara tersebut mendialogkan antara legal pluralism dan konstitusi negara. Teori pluralisme telah memberi gambaran bahwa dalam masyarakat tidak hanya berlaku satu hukum negara saja, melainkan ada hukum-hukum lain yang hidup di masyarakat. Pluralime hukum menempati ruang-ruang sosial dan saling bernegosiasi dalam ruang hukum negara. ${ }^{35}$ Globalisasi mempengaruhi pekembangan hukum sehingga membentuk ragam hukum. Meskipun begitu, tidak dapat dinafikan bahwa pluralisme hukum masih diperdebatan. Pluralisme hukum terkadang sering disajikan sebagai dua wajah hukum yang saling bersaing dalam menjawab tantangan hukum global. ${ }^{36}$ Pluralisme hukum seakan membantah paradigma legal centralism yang lebih menekankan hukum

26 Sally Engle Merry, “Legal Pluralism,” Law \& Society Review 22, no. 5 (1988): 869, https://doi.org/10.2307/3053638.

27 Merry. "Legal Pluralism," 869

28 Pedro Naso, Erwin Bulte, and Tim Swanson, "Legal Pluralism in Post-Conflict Sierra Leone," European Journal of Political Economy 61 (January 2020): 101819, https://doi.org/10.1016/j.ejpoleco.2019.101819.

${ }^{29}$ Charles Manga Fombad, "Reconciling Legal Pluralism and Constitutionalism: New Trajectories for Legal Theory in the Age of Globalisation in Botswana," in Debating Legal Pluralism and Constitutionalism, ed. Guillaume Tusseau, Ius Comparatum - Global Studies in Comparative Law (Cham: Springer International Publishing, 2020), 103-13, https://doi.org/10.1007/978-3-03034432-0_3.

30 Jaclyn L. Neo, "Legal Pluralism in Centralist Singapore," in Debating Legal Pluralism and Constitutionalism, ed. Guillaume Tusseau, Ius Comparatum - Global Studies in Comparative Law (Cham: Springer International Publishing, 2020), 251-71, https://doi.org/10.1007/978-3-030-34432-0 8.

31 María Carlota Ucín, “A Particular Dialogue Between Systems. The Argentinian Case,” in Debating Legal Pluralism and Constitutionalism, ed. Guillaume Tusseau, Ius Comparatum - Global Studies in Comparative Law (Cham: Springer International Publishing, 2020), 93-102, https://doi.org/10.1007/978-3-030-34432-0 2.

32 Ana Paula de Barcellos, "Brazil and Its Many Realities: Courts and State-Centrism; Administrative Agencies and International Cooperation," in Debating Legal Pluralism and Constitutionalism, ed. Guillaume Tusseau, Ius Comparatum - Global Studies in Comparative Law (Cham: Springer International Publishing, 2020), 115-35, https://doi.org/10.1007/978-3-030-34432-0_4.

33 Athanasios Psygkas, "Accommodating Legal Pluralism and 'Pluralizing' the Constitution: The Example of the United Kingdom," in Debating Legal Pluralism and Constitutionalism, ed. Guillaume Tusseau, Ius Comparatum - Global Studies in Comparative Law (Cham: Springer International Publishing, 2020), 305-31, https://doi.org/10.1007/978-3-030-34432-0_10.

34 Jennifer Corrin, "Constitutionalism and Customary Laws in Solomon Islands," in Debating Legal Pluralism and Constitutionalism, ed. Guillaume Tusseau, Ius Comparatum - Global Studies in Comparative Law (Cham: Springer International Publishing, 2020), 273-304, https://doi.org/10.1007/978-3-030-34432-0_9.

35 Paul Schiff Berman, "The New Legal Pluralism,” Annual Review of Law and Social Science 5, no. 1 (December 2009): 225-42, https://doi.org/10.1146/annurev.lawsocsci.093008.131539.

${ }^{36}$ Guillaume Tusseau, ed., Debating Legal Pluralism and Constitutionalism: New Trajectories for Legal Theory in the Global Age, vol. 41, Ius Comparatum - Global Studies in Comparative Law (Cham: Springer International Publishing, 2020), https://doi. org/10.1007/978-3-030-34432-0. 
negara. Padangan legal centralism memandang bahwa hukum merupakan susunan hirarki yang ideal (eksklusif), tersusus dan sistematis. Hukum terpusat kepada pemerintah sehingga hukum seragam dan digunakan oleh seluruh masyarakat. ${ }^{37}$

Kajian pluralisme hukum pada kenyataan sangat membantu terhadap pengembangan hukum yang hanya bersifat normatif pada negara-negara modern. ${ }^{38}$ Manarik apa yang disampaikan oleh John Griffiths bahwa;

Legal pluralism is the fact. Legal centralism is a myth, anideal, aclaim, anillusion. Nevertheless, the ideology of legal centralism has had such a powerful hold on the imagination of lawyers and social scientists that its picture of the legal world has been able successfully to masquerade as fact and has formed the foundation stone of social and legal theory. ${ }^{39}$

Lebih lanjut Griffiths membagi pluralisme hukum menjadi dua bagian yaitu pluralisme hukum lemah (weak) dan kuat (strong). Pliralisme hukum lemah ketika negara dengan sistem sentralisasi hukum mengakui hukum non-negara dan keberlakuannya dibawah hukum negara, sedangkan pluralisme hukum kuat mengakui dan memposisikan hukum non-negara sama kapasitasnya dengan hukum negara. ${ }^{40}$ Werner Menski yang terkenal dengan teori konsep segitiga pluralisme hukum (triangular concept of legal legal pluralism) telah menggambarkan beberapa konsep hukum yang telah dibahas oleh para pakar hukum dunia. ${ }^{41}$ Sebelum membahas pluralisme hukum, Menski mencoba memetakan pandangan dunia tentang hukum dan sumber hukum. Menski melihat bahwa pandangan hukum yang terpusat kepada negara (sistem sentral) dengan menganggap bahwa hukum nonnegara tidak legal tidak akan memberikan perubahan yang dinamis terhadap hukum. Oleh karena itu, Menski menawarkan konsep pluralisme hukum untuk menjawab hukum global. Tiga bentuk hukum yaitu Negara, sosial dan agama/etik/moral. Menski mengusulkan model pemahaman hukum yang terfokus pada pluralitas yang memperhitungkan secara implisit dari semua tiga elemen utama segitiga seperti yang ditunjukkan pada Gambar dibawah ini; ${ }^{42}$

Gambar. 1. Triangular Concept Of Legal Legal Pluralism

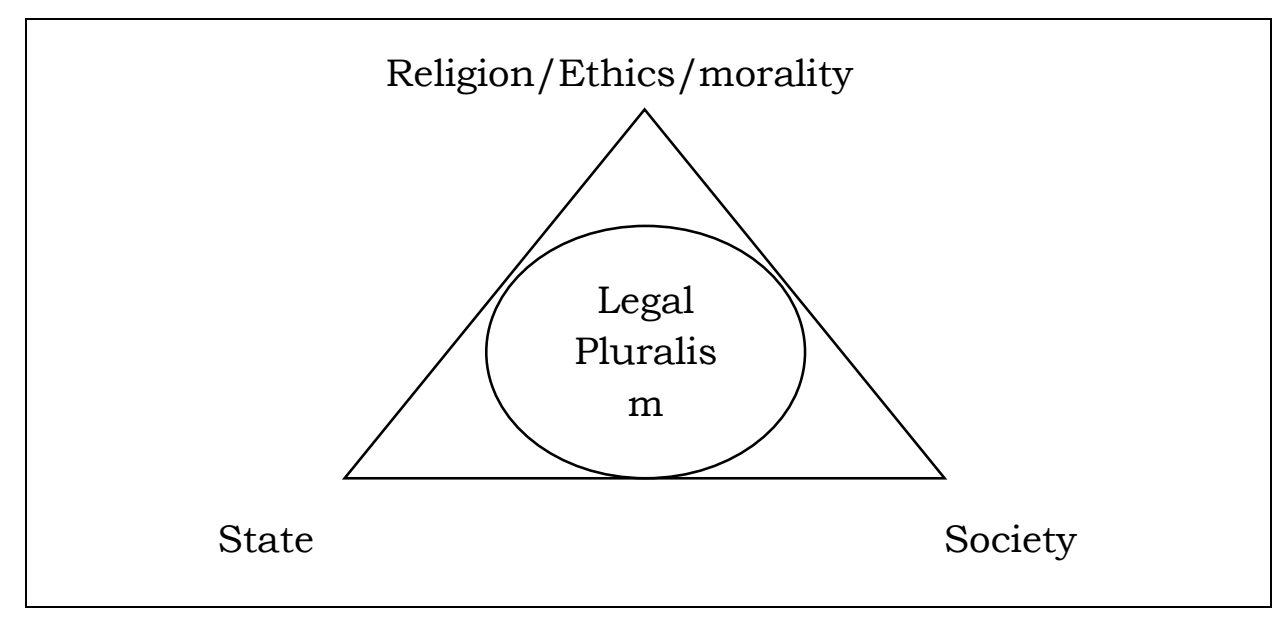

\footnotetext{
37 Griffiths, "What Is Legal Pluralism?" 1-55

38 Paul Schiff Berman, The Oxford Handbook of Global Legal Pluralism (United States of America: Oxford University Press, 2020). 25

39 Griffiths, "What Is Legal Pluralism?". 1-55

40 Griffiths. Griffiths.. 1-55

41 Achmad Ali, Menguak Teori Hukum \& Teori Peradilan: Legal Theory \& Judicialprudence, 5th ed. (Jakarta: Kencana, 2013)., 184

42 Menski, Comparative Law in a Global Context the Legal Systems of Asia and Africa. 184-190
} 
Gambar 1 di atas menunjukan bahwa pluralisme hukum akan menjadikan hukum yang ideal, ketika hukum yang ada di luar dimasukan kedalam lingkaran maka akan mengambarkan bahwa hukum dibentuk dari elemen-elemen yang beragam. Menski ingin mengungkapkan bahwa ketika melihat sesuatu harus secara universal tidak parsial, seperti melihat pohon. Maka, harus melihat unsur-unsur pohon secara menyeluruh, ranting, daun, akar, dahan dan lainnya. ${ }^{43}$

Gambaran pluralisme hukum seakan membantah paham positivism yang hanya menganggap bahwa hukum legal itu hanyalah hukum negara tanpa menganggap hukum yang berlaku diluar negara (non-state). Pluralisme hukum lebih mendukung teori Friedman tentang sistem hukum yang memasukan budaya hukum sebagai penentu bergeraknya hukum. Pluralisme hukum sejatinya tidak hanya berbicara tentang substansi hukum dan struktur hukum, jauh dari pada itu pluralisme hukum juga mengatur tentang budaya hukum yang oleh Friedman disebut "legal culture". ${ }_{44}$

\section{Tawaran Hukum Plural di Aceh}

Status yang disandang oleh Aceh sebagai provinsi yang memiliki kekhususan pasca-MOU memberikan angin segar bagi masyarakat dan "politisi" Aceh. Nyatanya MOU memberikan kewenangan bagi pemerintah Aceh untuk menerapkan aturan hukum yang berkearifan lokal. Hasil dari MOU melahirkan Undang-Undang Nomor 44 Tahun 1999 Tentang Keistimewaan Aceh yang semakin mempertegas posisi keistimewaan Aceh dalam menyelenggarakan pemerintahan. ${ }^{45}$ Undang-Undang tersebut merupakan bentuk pertanggung jawaban pemerintah Indonesia atas tuntutan masyarakat Aceh. Namun, pluralisme hukum tidak secara langsung dibentuk di bumi Aceh, pada tahun 2001 dengan dikeluarkannya Undang-Undang Nomor 18 Tahun 2001 Tentang Otonomi Khusus, Aceh baru dapat menerapkan syariat Islam sebagaimana yang diinginkan sebelum MOU.

Pada dasarnya dalam konstitusi Indonesia telah mengakui keragaman adat dan hak-hak tradisional, pemerintah mengakui bahwa hukum adat merupakan hukum yang hidup di masyarakat dan kewajiban pemerintah mengakomodir keragaman hukum adat. Hal ini juga diperkuat dengan Putusan Mahkamah Konstitusi Nomor 31/PUU-V/2007. Melalui putusan tersebut Mahkamah Konstitusi mengakui hukum adat apabila memenuhi empat 1) masih hidup, 2) sesuai dengan kondisi masyarakat, 3) sesuai prinsip negara, 4) diatur dalam Undang-undang. ${ }^{46}$ Meskipun begitu, pemerintah Aceh dengan pemerintah Indonesia ingin mempertegas dan memperjelas status bentuk pelaksanaan Pemerintahan Aceh, sehingga pemerintah mengesahkan beberapa Undang-Undang, antara lain; Pertama, Undang-Undang Nomor 44 Tahun 1999 Tentang Keistimewaan Aceh; Kedua, Undang-Undang Nomor 18 Tahun 2001 Tentang Otonomi Khusus; Ketiga, Undang-Undang Nomor 11 Tahun 2006 Tentang Pemerintah Aceh. ${ }^{47}$ Undang-undang tersebut merupakan pintu masuk lahirnya pluralisme hukum di Aceh.

Undang-Undang tentang Keistimewaan Aceh mengatur tentang penyelenggaraan keistimewaan aceh yang mencakup penyelenggaraan kehidupan beragama, kehidupan adat,

\footnotetext{
${ }^{43}$ Menski. Comparative Law in a Global Context the Legal Systems of Asia and Africa, 612-613

${ }^{44}$ Friedman, The Legal System. 15

45 Ridha Maulana et al., "Sistem Hukum Di Aceh Dan Kaitannya Dengan Pluralisme Hukum," Jurnal Geuthèë: Penelitian Multidisiplin 2, no. 3 (2019): 9.

${ }^{46}$ Zaka Firma Aditya, "Romantisme Sistem Hukum Di Indonesia : Kajian Atas Konstribusi Hukum Adat Dan Hukum Islam Terhadap Pembangunan Hukum Di Indonesia,” Jurnal Rechts Vinding: Media Pembinaan Hukum Nasional 8, no. 1 (May 15, 2019): 37, https://doi.org/10.33331/rechtsvinding.v8i1.305.

47 Salim, "Dynamic Legal Pluralism in Indonesia.". 8
} 
pendidikan dan peran ulama. Peraturan ini mengarah kepada aturan umum tetang objek dan arah kebijakan peraturan pemerintah Aceh. Lebih detail Undang-Undang Nomor 11 Tahun 2006 Tentang Pemerintah Aceh mengatur sistem pemerintahan Aceh dan lembaga adat, ditambah lagi dengan lahirnya Undang-Undang Nomor 18 Tahun 2001 Tentang Otonomi Khusus semakin memperjelas pluralisme hukum di Aceh, beberapa lembaga lahir melalui undang-undang tersebut, seperti lembaga adat, peradilan adat, ${ }^{48}$ Mahkamah Syari'iyah, Majelis Adat Aceh, Majelis Permusyawaratan Ulama, Dinas Syariat Islam, Wilayatul Hisbah, Majelis Pendidikan Daerah, Lembaga Wali Nanggroe. Bahkan berbagai qanun terus lahir dan menggeser hukumhukum nasional, seperti lahirnya qanun jinayat, Acara Jinayat. bahkan saat ini pemerintah Aceh sedang menyiapkan qanun munakahat. Meskipun begitu, hukum nasional tetap berlaku di Aceh dan saling berdampingan dalam menyelesaikan permasalahan hukum di Aceh. Karena melalui Undang-Undang Nomor 32 Tahun 2004 menegaskan bahwa bentuk pemerintahan daerah yaitu desentralisasi.

Meskipun pluralisme hukum terus berkembang di Aceh. Namun, kelihatannya pemerintah baik pemerintah daerah dan pemerintahan pusat belum mampu menjebatani problematika hukum perceraian di Aceh, hingga saat ini di Aceh masih terjadi pedebatan antara masyarakat, MPU dan Pemerintah Indonesia terkait dengan hukum perceraian di Aceh.

\section{Islam, Fatwa dan Negara: Potret Hukum Perceraian di Aceh}

Banyak faktor yang mendasari terjadinya perceraian di Indonesaia, setidakya dapat diklasifikasikan kepada 2 (dua) faktor, antara lain faktor internal dan eksternal. Faktor internal termasuk ekonomi, ${ }^{49}$ sexualitas, KDRT sedangkan fakto eksternal meliputi lingkungan sosial, pendidikan. Faktor eksternal cukup mempengaruhi terjadinya perceraian. Pergeseran sosial turut serta mempengaruhi terjadinya perceraian. ${ }^{50}$ Tidak hanya itu saja, tren nikah muda juga menjadi pemicu perceraian ketika praktik pernikahan tidak sesuai dengan angan-angan dan harapan dicita-citakan. Begitu juga dengan Aceh, perceraian didominasi oleh gugat cerai, pada tahun 2020 bulan terhitung jumlah perceraian sebanyak 2.397 perkara yang terdiri dari gugat cerai sebanyak 1.737 perkara dan cerai gugat sebanyak 660 perkara. ${ }^{51}$ Jumlah cerai gugat di Aceh merupakan data cerai talak yang terdapat dipengadilan, sedangkan di luar pengadilan sulit untuk didata mengingat jangkauan perceraian yang luas dan tertutup menjadi kendala tersendiri.

Cerai di pengadilan atau diluar pengadilan merupakan pilihan hukum yang nantinya akan berdampak kepada setiap pasangan pasca perceraian. Pilihan hukum tersebut dipengaruhi oleh latar belakang pendidikan, sehingga ditengah-tengah masyarakat dominasi mazhab fikih merasa perlu adanya kepastian hukum tentang status pernikahan, dalam kondisi seperti ini pengadilan menjadi pilihan utama dalam penyelesaian perceraian. Faktor pendidikan cukup signifikan dalam membangun

\footnotetext{
${ }^{48}$ Nanda Amalia, Mukhlis Mukhlis, and Yusrizal Yusrizal, "Model Penyelesaian Sengketa Dan Peradilan Adat Di Aceh," Jurnal Hukum Ius Quia Iustum 25, no. 1 (January 2018): 159-79, https://doi.org/10.20885/iustum.vol25.iss1.art8.

49 Noeranisa Adhadianty Gunawan and Nunung Nurwati, "Persepsi Masyarakat Pada Perceraian Society Perception Of Divorce," Share: Social Work Journal 9, No. 1 (2019): 2, https://doi.org/10.24198/share.v9i1.19863.

50 Tim Heaton and Mark Cammack, "Explaining the Recent Upturn in Divorce in Indonesia: Developmental Idealism and the Effect of Political Change," Asian Journal of Social Science 39, no. 6 (2011): 776-96, https://doi.org/10.1163/156853111X619229.

51 Kompas.com, "5 Bulan Terakhir, Kasus Perceraian Di Aceh Capai 2.397, Ternyata Ini Pemicunya," Regional.Kompas.com, June 11, 2020, https://regional.kompas.com/read/2020/06/11/14400081/5-bulan-terakhir-kasus-perceraian-di-aceh-capai2.397-ternyata-ini-pemicunya.
} 
pengetahuan hukum, perilaku hukum, etika hukum masyarakat dalam memahami dampak hukum yang ditimbulkan ketika tidak mengikuti prosedur hukum yang telah ditatur oleh Negara. ${ }^{52}$ Sebaliknya, bagi mayoritas masyarakat awam yang lebih memilih mengikuti hukum setempat yang telah lama diberlakukan (living law).

Dalam konteks living law tentang cerai talak di Aceh, kecendrungan fikih mazhab Syafi'i telah terpolarisasi sehingga mazhab hukum lokal sulit untuk digantikan dengan hukum-hukum lain ketika terjadinya friksi hukum. Bagi mayoritas masyarakat tradisionalis mengganggap bahwa hukum fikih lebih utama ketimbang hukum Negara ketika terjadi persinggungan hukum yang berkaitan dengan hukum Islam. Dalam konteks hukum cerai talak di Aceh, persinggungan hukum antara fatwa dan Undang-Undang Perkawinan mempengaruhi pilihan hukum bagi masyarakat Aceh. Semangat fikih yang diyakini oleh mayoritas masyarakat Aceh berefek kepada aspek penerapan hukum.

Fatwa MPU Aceh Nomor 2 Tahun 2015 Tentang Talak pada poin kedua menetapkan bahwa jatuhnya talak tiga ketika suami mengucapan talaknya baik diucapkan sekaligus maupun tidak, artinya bahwa ketika terjadi talak tiga yang diucapkan oleh suami maka secara hukum fikih tergolong talak ba 'in kubra yang mengakibatkan suami tidak dapat merujuk kembali istrinya.

Setidaknya ada empat poin penting ketetapan fatwa MPU Aceh tentang Talak, antara lain sebagai berikut:

1. Talak merupakan pemutusan ikatan perkawinan dengan lafadh talak atau lainnya;

2. Talak tiga baik sekali ucap maupun tiga kali ucap jatuh talak tiga;

3. Talak yang dilakukan diluar pengadilan dan/atau talak yang dilakukan tanpa adanya saksi adalah sah;

4. Taushiyah

Pada ketetapan poin keempat berisakan tentang taushiyah yang terdiri dari enam taushiyah, antara lain; pertama, harapan kepada pemerintah Aceh untuk segera membentuk qanun munakahat; kedua, harapan kedapa pemerintah sebelum lahirnya qanun munakahat untuk mengusulkan kepada Mahkamah Syar'iyah untuk menggunakan fatwa ini sebagai rujukan dalam memutuskan perkara talak guna untuk menghindari perbedaan pendapat dan perpechan umat; ketiga, Diharapkan kepada Mahkamah Syar'iyah untuk memeriksa dengan cermat dan akurat Talak yang dijatuhkan di luar pengadilan dan menetapkan dalam suatu keputusan; keempat, Diharapkan kepada Kantor Urusan Agama (KUA) Kecamatan dan atau pihak yang berwenang untuk mengoptimalkan pembekalan dan penguatan pengetahuan calon pasangan suami-istri dalam upaya pencegahan terjadinya Talak semena-mena; kelima, Diharapkan kepada masyarakat agar menghindari hal-hal yang mengarah kepada putusnya ikatan perkawinan; keenam, Diharapkan kepada Kantor Kementerian Agama Aceh dan pihak terkait agar mensosialisasikan fatwa ini.

Ketetapan fatwa MPU Aceh tentang talak secara normatif berbeda dengan konsep cerai talak yang diatur dalam peraturan perkawinan di Indonesia. Poin kedua dalam fatwa tersebuat berpengaruh besar terhadap masyarakat Aceh, secara sosiologis fatwa talak yang dikeluarkan oleh MPU Aceh berangkat dari kegelisahan masyarakat Aceh terhadap dualisme hukum yang terjadi. Fatwa tersebut bersifat lokal karena secara historis muncul fatwa MPU tentang talak tidak terlepas dari hukum

\footnotetext{
52 Junaidi Junaidi, Muhammad Rusdi Bin Muhammadiah, and Muhazir Muhazir, "Revitalisasi Penerapan Qanun Nomor 6 Tahun 2014 tentang Hukum Jinayat di Kota Langsa Aceh,” Al-Manahij: Jurnal Kajian Hukum Islam 14, no. 1 (June 2, 2020): 147-60, https://doi.org/10.24090/mnh.v14i1.3261.
} 
perceraian yang hidup di masyarakat Aceh. Model istinbat hukum yang dilakukan oleh MPU Aceh tentang talak menggunakan pendekatan tekstual yang mengarah kepada mazhab fikih terutama fikih Syafi'iyah, meskipun dalam fatwa dicantumkan juga bahwa acuan dasar yang digunakan yaitu dengan menggali sumber-sumber hukum Islam yang terdapat dalam al-Quran, al-Hadis, Ijma' Ulama, Qiyas, Pendapat Ulama, Qawa'id Fiqhiyah dan Qawa'id Ushuliah. Selain melihat sumber hukum Islam, MPU juga melihat ketentuan talak yang berlaku pada undang-undang perkawinan dan Qanun yang terkait dengan syariat Islam di Aceh.

Sumber hukumyang digunakan dalam Undang-Undang Nomor 1 Tahun 1974 tentang perkawinan dan KHI memiliki kesamaan dengan fatwa, hanya saja ada beberapa pembaharuan hukum yang dianggap perlu disesuaikan dengan konteks Negara, ditambah lagi multikultural keagamaan di Indonesia tidak kaku pada satu mazhab fikih. Meskipun ada yang berpendapat bahwa dengan adanya Undang-Undang Perkawinan semakin melemahkan fikih munakahat. Namun, pendapat tersebut dibantah dengan argumentasi bahwa Undang-undang Perkawinan merupakan produk ijtihat yang memiliki kedudukan penting dalam penemuan hukum Islam..$^{53}$

Dalam Undang-Undang Nomor 1 Tahun 1974 pada pembasahan perceraian hanya memberi penjelasan umum saja, tidak mengatur secara spesifik tentang perdebatan talak tiga. Hal ini lumrah saja, karena mengingat UU bersifat mengatur secara universal dan untuk lebih rincinya dapat dilihat dalam aturan pelaksana atau dapat juga melihat KHI. Pada pasal 38 dalam Undang-Undang Perkawinan hanya menjelaskan bahwa putusnya perkawinan karena kematian, perceraian dan putusan pengadilan. Ketika ditelusuri lebih lanjut bahwa perceraian yang dimaksud dalam UndangUndang Perkawinan tersebut adalah cerai gugat dan gugat cerai, sedangkan dalam fikih perihal perceraian tidak hanya terbatas kepada cerai gugat dan gugat cerai saja, ada khuluk, Li'an, Ila' dan Nusyuz.

Selain Undang-Undang Perkawinan, pemerintah melalui KHI berusaha mengatur ketentuan cerai talak secara jelas untuk melengkapi kekurangan yang ada dalam Undang-Undang Perkawinan. KHI merupakan Intruksi Presiden kepada pengadilan Agama/Mahkamah Syar'iyah untuk digunakan dalam meyelesaikan sengketa keluarga Islam. Namun, tidak semua hakim Pengadilan Agama terikat dengan KHI. ${ }^{54}$ Meskipun secara legalitas kedudukan KHI tidak bersifat mengikat layaknya perundang-undangan. Tetapi, KHI sebagai Inpres memiliki daya ikat dan memaksa pada pihak yang diperintah, ${ }^{55}$ ditambah lagi dengan kehadiran KHI dapat meminimalisis perdebatan hukum perceraian, karena sumber hukum KHI yang berasal dari kajian kitab-kitab klasik ditambah lagi dominasi mazhab Syafi'i dalam materilnya semakin menambah respond positif bagi kalangan ulama dan masyarakat yang notabennya menganut mazhab Syafi'i. ${ }^{56} \mathrm{Namun}$, dalam konteks cerai talak KHI tidak mengikuti secara menyeluruh mazhab Syafi'i, KHI menetapkan bahwa cerai talak yang dijatuhkan di pengadilan tetap pada talak ba'in sughra.

Perbedaan pemahaman hukum perceraian antara masyarakat, MPU dengan pemerintah semakin memperkeruh percaraian sehingga tidak menutup kemungkinan masyarakat lebih memilih

\footnotetext{
53 Muhammad Tahir Azhary, "Hukum Perkawinan Islam Dan Uu No. 1 Tahun 1974,” Jurnal Hukum \& Pembangunan 17, No. 1 (2017): 49, https://doi.org/10.21143/jhp.vol17.no1.1224.

54 Alfitri Alfitri, "Sharia Judges Role in Indonesia: Between The Common Law and The Civil Law Systems," Mazahib 16, no. 2 (August 30, 2017): 120, https://doi.org/10.21093/mj.v16i2.825.

55 Marzuki Wahid \& Rumadi, Figh Madzhab Negara; Kritik atas Politik Hukum Islam di Indonesia (Lkis Pelangi Aksara, 2001), 192

${ }^{56}$ Khairul Umam, "Penyerapan Fiqh Madzhab Syafi'i dalam Penyusunan Kompilasi Hukum Islam,” Journal de Jure 9 , no. 2 (December 30, 2017): 117, https://doi.org/10.18860/j-fsh.v9i2.6991.
} 
cerai di luar pengadilan. Permasalahan ini akan terus-menerus berlanjut ketika pemerintah tidak mengakomodir hukum yang berlaku di masyarakat. Dalam pandangan pluralisme hukum pemerintah seyogyanya melihat hukum yang hidup dan budaya hukum yang dipraktikan oleh masyarakat sebagaimana yang diungkapkan oleh Eugen Ehrlich tentang konsep living law. Terkecuali pemerintah mengambil paham positivisme dengan membuat aturan yang bersifat memaksa masyarakat Aceh untuk mengikuti aturan yang telah ditetapkan oleh pemerintah. Tapi pandangan ini sangat keliru ketika dilihat dari sudut pandang pluralisme hukum. Ketika dilihat dari pluralisme hukum perspektif Menski. Maka, ketika pemerintah ingin hukum perceraian berjalan dengan tertib harus mengikuti kehendak hukum rakyat yang bersumber dari agama dan fatwa yang lebih diyakini bagi manyoritan muslim Aceh.

Ketika dilihat dari aspek pluralisme hukum maka perlu kiranya mengakomodir hukum yang dianut oleh masyarakat (non-state) kedalam hukum negara (state), tidak hanya itu saja, hakim agama turut dalam proses pluralisme hukum, karena posisinya sebagai pihak yang memutuskan perkara perceraian di Indonesia, hal ini dapat dijelaskan dalam gambar dibawah ini;

\section{Gambar 2: Pluralisme Peraturan Perceraian di Aceh}

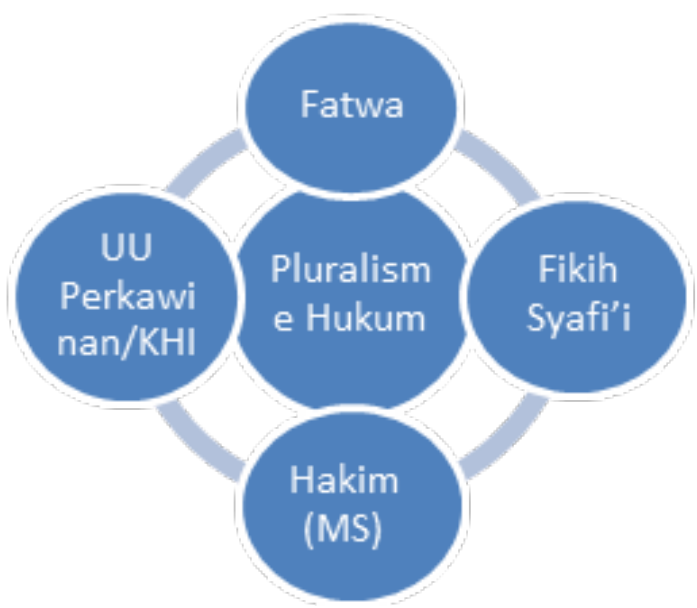

Gambar 2 di atas merupakan rangkaian proses pluralisme hukum perceraian di Aceh, fikih mazhab Syafi'I, hakim Mahkamah Syar'iyah, Undang-Undang Perkawinan serta fatwa yang merupakan produk hukum MPU Aceh saling berkaitan satu sama lainnya, sehingga ketika keempat elemen tersebut menyatu dan dipraktikan kedalam pengambilan keputusan hakim Mahkamah Syar'iyah akan menjadikan suatu solusi ketika terjadi ambiguitas hukum perceraian ditengah masyarakat Aceh.

Jalan tengah yang dapat ditempuh oleh pemerintah yaitu memberlakukan perceraian khusus bagi masyarakat Aceh dengan mengacu kepada mazhab hukum perkawinan (fikih) yang dipegang teguh oleh masyarakat Aceh. Atau pemerintah dapat juga memberikan opsi perceraian yang ingin ditempuh oleh masyarakat. Hal ini lebih mencerminkan sikap pluralisme hukum. Sebagaimana yang pernah diterapkan oleh dinasti Abbashiah yang menempatkan hakim pada pengadilan dengan empat mazhab, sehingga masyarakat dapat memilih hukum yang diyakini dan dijalankan pada aktivitas sehari-hari. 


\section{Penutup}

Pluralisme hukum di Aceh merupakan cerminan hukum Indonesia dalam menyikapi ragam hukum yang terjadi. Dalam konstitusi pemerintah pada dasarnya tenlah mengakui ragam hukum dan agama yang ada di Indonesia. Keragaman budaya dan agama semakin memaksa pemerintah untuk lebih maksimal dalam menciptakan hukum yang dapat mengakomodir hukum-hukum yang hidup ditengah masyarakat. Hukum perceraian yang terjadi di Aceh menggambarkan bahwa terjadinya tarik ulur hukum yang disebabkan oleh perbedaan pandangan hukum cerai. Akibatnya hukum percaraian tidak berjalan dengan makasimal, karena terjadinya perbedaan antara hukum agama dan negara. Ketaatan masyarakat kepada hukum agama nyatanya mengalahkan ketaatannya kepada hukum negara, meskipun sebagian intelektual muslim mengganggap bahwa ketentuan hukum perceraian yang diatur oleh pemerintah dalam UU Perkawinan dan KHI merupakan terobosan hukum yang lebih mashlahah bagi setiap individu dan negara. Dibutuhkan keseriusan pemerintah untuk mendudukan perbedaan tersebut dan mengakomodir apa yang diinginkan oleh masyarakat sebagaimana semangat hukum yang dirumuskan oleh Eugen Ehrlich, Werner Menski dan Lawrence M. Friedman tentang hukum.

\section{Daftar Pustaka}

Aditya, Zaka Firma. "Romantisme Sistem Hukum Di Indonesia : Kajian Atas Konstribusi Hukum Adat Dan Hukum Islam Terhadap Pembangunan Hukum Di Indonesia.” Jurnal Rechts Vinding: Media Pembinaan Hukum Nasional 8, no. 1 (May 15, 2019): 37. https://doi.org/10.33331/rechtsvinding. v8i1.305.

Alfitri, Alfitri. "Sharia Judges Role in Indonesia: Between The Common Law and The Civil Law Systems." Mazahib 16, no. 2 (August 30, 2017): 120. https://doi.org/10.21093/mj.v16i2.825.

Ali, Achmad. Menguak Teori Hukum \& Teori Peradilan: Legal Theory \& Judicialprudence. 5th ed. Jakarta: Kencana, 2013.

Amalia, Nanda, Mukhlis Mukhlis, and Yusrizal Yusrizal. "Model Penyelesaian Sengketa Dan Peradilan Adat Di Aceh." Jurnal Hukum Ius Quia Iustum 25, no. 1 (January 2018): 159-79. https://doi. org/10.20885/iustum.vol25.iss1.art8.

Azhary, Muhammad Tahir. "Hukum Perkawinan Islam dan UU No. 1 Tahun 1974." Jurnal Hukum \& Pembangunan 17, no. 1 (June 14, 2017): 49. https://doi.org/10.21143/jhp.vol17.no1.1224.

Barcellos, Ana Paula de. "Brazil and Its Many Realities: Courts and State-Centrism; Administrative Agencies and International Cooperation." In Debating Legal Pluralism and Constitutionalism, edited by Guillaume Tusseau, 115-35. Ius Comparatum - Global Studies in Comparative Law. Cham: Springer International Publishing, 2020. https://doi.org/10.1007/978-3-030-34432-0_4.

Benton, Lauren, and Richard J. Ross. Legal Pluralism and Empires, 1500-1850. U.S.A.: NYU Press, 2013.

Berman, Paul Schiff. "The New Legal Pluralism." Annual Review of Law and Social Science 5, no. 1 (December 2009): 225-42. https://doi.org/10.1146/annurev.lawsocsci.093008.131539.

-- - The Oxford Handbook of Global Legal Pluralism. United States of America: Oxford University Press, 2020. 
Bowen, John R. Islam, Law, and Equality in Indonesia an Anthropology of Public Reasoning. Cambridge, UK; New York, NY: Cambridge University Press, 2003.

Corrin, Jennifer. "Constitutionalism and Customary Laws in Solomon Islands." In Debating Legal Pluralism and Constitutionalism, edited by Guillaume Tusseau, 273-304. Ius Comparatum - Global Studies in Comparative Law. Cham: Springer International Publishing, 2020. https://doi. org/10.1007/978-3-030-34432-0_9.

Djumala, Darmansjah. Soft Power untuk Aceh. Jakarta: Gramedia Pustaka Utama, 2013.

Feener, R. Michael. Shari'a and Social Engineering: The Implementation of Islamic Law in Contemporary Aceh, Indonesia. First edition. Oxford Islamic Legal Studies. Oxford, United Kingdom: Oxford University Press, 2013.

Fombad, Charles Manga. "Reconciling Legal Pluralism and Constitutionalism: New Trajectories for Legal Theory in the Age of Globalisation in Botswana." In Debating Legal Pluralism and Constitutionalism, edited by Guillaume Tusseau, 103-13. Ius Comparatum - Global Studies in Comparative Law. Cham: Springer International Publishing, 2020. https://doi.org/10.1007/9783-030-34432-0_3.

Friedman, Lawrence M. The Legal System: A Social Science Perspective. New York: Russell Sage Foundation, 1975.

Griffiths, John. "What Is Legal Pluralism?” The Journal of Legal Pluralism and Unofficial Law 18, no. 24 (January 1986): 1-55. https://doi.org/10.1080/07329113.1986.10756387.

Grijns, Mies, and Hoko Horii. "Child Marriage in a Village in West Java (Indonesia): Compromises between Legal Obligations and Religious Concerns." Asian Journal of Law and Society 5, no. 2 (November 2018): 453-66. https://doi.org/10.1017/als.2018.9.

Gunawan, Noeranisa Adhadianty, and Nunung Nurwati. "Persepsi Masyarakat Pada Perceraian Society Perception Of Divorce." Share: Social Work Journal 9, no. 1 (August 5, 2019): 20. https:// doi.org/10.24198/share.v9i1.19863.

Harahap, Ikhwanuddin. "Pluralisme Hukum Perkawinan Di Tapanuli Selatan." Miqot: Jurnal Ilmu-ilmu Keislaman 43, no. 1 (December 30, 2019): 64. https://doi.org/10.30821/miqot.v43i1.656.

Heaton, Tim, and Mark Cammack. "Explaining the Recent Upturn in Divorce in Indonesia: Developmental Idealism and the Effect of Political Change." Asian Journal of Social Science 39, no. 6 (2011): 776-96. https://doi.org/10.1163/156853111X619229.

Hosen, Nadirsyah. "Nahdlatul Ulama And Collective Ijtihad:" New Zealand Journal of Asian Studies 6, no. 1 (2004): 22.

Ichwan, M. N. "Official Ulema and the Politics of Re-Islamization: The Majelis Permusyawaratan Ulama, Sharilhringatization and Contested Authority in Post-New Order Aceh." Journal of Islamic Studies 22, no. 2 (May 1, 2011): 183-214. https://doi.org/10.1093/jis/etr026.

Jamhir, Jamhir. "Revitalisasi Hukum Adat Di Aceh.” Jurnal Justisia: Jurnal Ilmu Hukum, PerundangUndangan Dan Pranata Sosial 1, no. 1 (July 8, 2020): 68-90. https://doi.org/10.22373/justisia. v1i1.2562.

Junaidi, Junaidi, Muhammad Rusdi Bin Muhammadiah, and Muhazir Muhazir. "Revitalisasi Penerapan Qanun Nomor 6 Tahun 2014 tentang Hukum Jinayat di Kota Langsa Aceh.” Al-Manahij: Jurnal Kajian Hukum Islam 14, no. 1 (June 2, 2020): 147-60. https://doi.org/10.24090/mnh.v14i1.3261. 
Kharel, Amrit. "Doctrinal Legal Research.” South African Journal of Higher Education 32, no. 1 (2018): 86. https://doi.org/10.2139/ssrn.3130525.

Kompas.com.“5BulanTerakhir,KasusPerceraianDiAcehCapai2.397, TernyataIniPemicunya.”Regional. Kompas.com, June 11, 2020. https://regional.kompas.com/read/2020/06/11/14400081/5bulan-terakhir-kasus-perceraian-di-aceh-capai-2.397-ternyata-ini-pemicunya.

Masyithoh, Novita Dewi. "Dialektika Pluralisme Hukum: Upaya Penyelesaian Masalah Ancaman Keberagaman dan Keberagamaan di Indonesia." Walisongo: Jurnal Penelitian Sosial Keagamaan 24, no. 2 (December 15, 2016): 359-78. https://doi.org/10.21580/ws.24.2.1289.

Maulana, Ridha, O D Kurniawati, D P Ananda, and Arsudian Putra. "Sistem Hukum Di Aceh Dan Kaitannya Dengan Pluralisme Hukum.” Jurnal Geuthëë: Penelitian Multidisiplin 2, no. 3, 2019.

Menski, Werner. Comparative Law in a Global Context the Legal Systems of Asia and Africa. London: Cambridge University Press, 2006.

Merry, Sally Engle. “Legal Pluralism.” Law \& Society Review 22, no. 5 (1988): 869. https://doi. org/10.2307/3053638.

Muhdlor, Ahmad Zuhdi. "Perkembangan Metodologi Penelitian Hukum.” Jurnal Hukum dan Peradilan 1, no. 2 (July 31, 2012): 189. https://doi.org/10.25216/JHP.1.2.2012.189-206.

Naso, Pedro, Erwin Bulte, and Tim Swanson. "Legal Pluralism in Post-Conflict Sierra Leone." European Journal of Political Economy 61 (January 2020): 101819. https://doi.org/10.1016/j. ejpoleco.2019.101819.

Neo, Jaclyn L. "Legal Pluralism in Centralist Singapore." In Debating Legal Pluralism and Constitutionalism, edited by Guillaume Tusseau, 251-71. Ius Comparatum - Global Studies in Comparative Law. Cham: Springer International Publishing, 2020. https://doi.org/10.1007/978-3-030-34432-0_8.

Nirzalin, Nirzalin, and Yogi Febriandi. "Teungku Dayah Agency and Religious Social Capital on Drug Eradication in Aceh, Indonesia." Jurnal Ilmu Sosial Dan Ilmu Politik 23, no. 3 (May 21, 2020): 210. https://doi.org/10.22146/jsp.51061.

Psygkas, Athanasios. "Accommodating Legal Pluralism and 'Pluralizing' the Constitution: The Example of the United Kingdom." In Debating Legal Pluralism and Constitutionalism, edited by Guillaume Tusseau, 305-31. Ius Comparatum - Global Studies in Comparative Law. Cham: Springer International Publishing, 2020. https://doi.org/10.1007/978-3-030-34432-0_10.

Ratnapala, Suri. Jurisprudence: An Introduction. Leiden: Cambridge University Press, 2009.

Regime Change, Democracy and Islam: The Case of Indonesia. Belanda: Universiteit Leiden, 2013.

Rumadi, Marzuki Wahid \&. Fiqh Madzhab Negara: Kritik atas Politik Hukum Islam di Indonesia. Lkis Pelangi Aksara, 2001.

Salim, Arskal. "Dynamic Legal Pluralism in Indonesia: Contested Legal Orders in Contemporary Aceh.” The Journal of Legal Pluralism and Unofficial Law 42, no. 61 (January 2010): 1-29. https:// doi.org/10.1080/07329113.2010.10756640.

Sani, Hanisah Binte Abdullah. "State Law and Legal Pluralism: Towards an Appraisal." The Journal of Legal Pluralism and Unofficial Law 52, no. 1 (January 2, 2020): 82-109. https://doi.org/10.1080/07 329113.2020.1727726. 
Sumardi, Dedy. "Islam, Pluralisme Hukum dan Refleksi Masyarakat Homogen." Asy-Syir'ah Jurnal Ilmu Syari'ah dan Hukum 50, no. 2 (2016): 24.

Tas, Latif. Legal Pluralism in Action: Dispute Resolution and the Kurdish Peace Committee. Farnham, Surrey, UK England: Ashgate, 2014.

Tusseau, Guillaume, ed. Debating Legal Pluralism and Constitutionalism: New Trajectories for Legal Theory in the Global Age. Vol. 41. Ius Comparatum - Global Studies in Comparative Law. Cham: Springer International Publishing, 2020. https://doi.org/10.1007/978-3-030-34432-0.

Ucín, María Carlota. “A Particular Dialogue Between Systems. The Argentinian Case.” In Debating Legal Pluralism and Constitutionalism, edited by Guillaume Tusseau, 93-102. Ius Comparatum Global Studies in Comparative Law. Cham: Springer International Publishing, 2020. https://doi. org/10.1007/978-3-030-34432-0_2.

Umam, Khairul. "Penyerapan Fiqh Madzhab Syafi'i dalam Penyusunan Kompilasi Hukum Islam." Journal de Jure 9, no. 2 (December 30, 2017): 117. https://doi.org/10.18860/j-fsh.v9i2.6991.

Zulkarnain, Zulkarnain. "Dinamika mazhab Shafi'i dengan cara Aceh: Studi tentang praktik mazhab di kalangan tokoh agama." Ijtihad: Jurnal Wacana Hukum Islam dan Kemanusiaan 15, no. 2 (January 22, 2016): 159. https://doi.org/10.18326/ijtihad.v15i2.159-176. 
